\title{
Platelet Aggregation Effect of Corchorus Olitorus Extract as an Index of Managing Blood Clotting Disorders
}

\author{
Omeje Kingsley Ozioma ${ }^{1}$, Odiba Arome Solomon ${ }^{1}$, Ejembi Daniel Ocholi ${ }^{2}$, \\ Chukwuka Raleke Somadina ${ }^{1}$ \\ ${ }^{1}$ Department of Biochemistry, University of Nigeria, Nsukka, Enugu State, Nigeria. \\ ${ }^{2}$ Department of Biochemistry, Kogi State University, Anyigba, Kogi State, Nigeria.
}

\begin{abstract}
The study investigated the effect of Corchorus olitorus extract on platelet aggregation, following oral administration of normal rat feed, $2 \mathrm{ml} / \mathrm{kg}$ body weight of normal saline, $50 \mathrm{mg} / \mathrm{kg}, 100 \mathrm{mg} / \mathrm{kg}$ and $200 \mathrm{mg} / \mathrm{kg}$ body weight of the extract to five groups of six rats each for fourteen days. Platelet rich plasma was extracted from the experimental animals and analyzed using a spectrophotometer. The results of the aggregation test show that Corchorus olitorus has the ability to aggregate blood platelets.
\end{abstract}

Keywords: Aggregation, Corchorus olitorus, Glandzman thrombasthenia, Platelet

\section{Introduction}

The use of plants for the treatment of different ailments had contributed immensely to the well being of humans and animals. The use of plants for medicinal purposes was recorded in the pharmacopoeia of Emperor Shen Nung of China between 273 and 300BC [1]. This shows that the use of plant for medicinal purposes is as old as human existence. According to [2], traditional medicine is defined as the local combination of knowledge and practice used in diagnosing, preventing or eliminating physical, mental and social disorders. This may rely on past experiences or observations handed down from generation to generation while bearing in mind the original concept of nature.

Some indigenous medicinal plants like C. olitorus among others, form important part of the natural wealth of Nigeria. [3], reported that estimated $80 \%$ of the world's population skill rely on traditional medicine for health care needs. Corchorus olitorus known as jute plant has been used in different parts of the world, including Asia and Africa. C. olitorus possesses the ability of remedying and preventing diseases. Plants possess some curative potential which depend on the occurrence of varieties of chemicals in the plant [4]. They contain high quantity of vitamin A, proteins, fibre, calcium, iron, carotene and folic acid [5]. C. olitorus is not only used as spices for food but also for the treatment of chronic cystitis and dysuria [6]. Corchorus capsularis (white jute) and Corchorus olitorus (tossa jute) are common varieties found in Nigeria.

\section{Materials And Methods}

2.1 Collection and Identification of Plant Material: Fresh leaves of C. olitorus were collected from EkeAwka in Awka South L.G.A, Anambra State of Nigeria for the study. The plant sample was authenticated by Prof. C.O. Okeke, a taxonomist at Department of Botany, Nnamdi Azikiwe University, Awka.

2.2 Preparation of Plant Material: The leaves were dried at room temperature for four days and pulverized with an electric blender. The powdered plant material that weighed $450 \mathrm{~g}$ was soaked in 1 litre of $70 \%$ ethanol for 48 hours. The extract was filtered and concentrated by indirect heating using water bath. The yield was $3.46 \%$ of the dried pulverized sample of the leaves.

2.3 Preparation of the Animal Samples: 30 adult albino rats that weighed between 100 and $150 \mathrm{~g}$ were obtained from the animal house of the Department of Zoology, University of Nigeria, Nsukka. The animals were fed commercial feed (top feed grower's mash).

Table 1: The nutrient composition of the feed

\begin{tabular}{ll}
\hline Nutrient & Composition \\
\hline Crude Protein & $16 \%$ \\
Minimum Energy & $11.1 \mathrm{KJ}$ \\
Calcium & $1.0 \%$ \\
Phosphorus & $0.7 \%$ \\
Fibre & $7.0 \%$ \\
Oil & $5.0 \%$ \\
\hline
\end{tabular}


The experimental animals were divided into 5 groups of six rats each. The control group received $2 \mathrm{ml} / \mathrm{kg}$ body weight of normal saline for fourteen days. Group II received $200 \mathrm{mg} / \mathrm{kg}$ body weight of the ethanol extract. Group III received $100 \mathrm{mg} / \mathrm{kg}$ body weight and group IV received $50 \mathrm{mg} / \mathrm{kg}$ body weight of the ethanol extract. Group V was used for in vitro test; the rats in this group received normal feed for the period of fourteen days. Ethanol extract of C. olitorus was administered orally once every day for 14 days to animals in groups II, III and IV. On the 14th day, the animals were sacrificed using chloroform as sedative agent and their blood samples collected and poured into sample bottles containing trisodium citrate as the anti coagulant. Each sample bottle was thoroughly mixed to prevent coagulation of the blood.

2.4 Preparation of the Platelet-Rich Plasma (PRP): Animal blood that measured $2 \mathrm{ml}$ was drawn into a sample container. The samples were centrifuged at 300rpm for 15 minutes and the supernatants were drawn into another set of containers [7]. A volume of $0.5 \mathrm{ml}$ of platelet-rich plasma (PRP) and $2 \mathrm{ml}$ of normal saline were mixed thoroughly and allowed to stand for a minute before adding $0.1 \mathrm{ml}$ of $4 \mathrm{mM} \mathrm{CaCl}$. The mixture was then put in cuvette of a spectrophotometer and the readings were taken immediately at a wavelength of $600 \mathrm{~nm}$ after every one minute for 5 minutes.

Statistical Analysis: Statistical comparisons were made using the student's T-test. A value of $\mathrm{P}<0.05$ was considered statistically significant.

\section{Results And Discussion}

The effect of ethanol extract of Corchorous olitorus on platelet aggregation was evaluated. There were progressive decreases in the absorbance of the different groups of the experimental samples with time which implies that the extract encouraged the aggregation of platelets. Tables 2, 3 and 4 show that the higher the doses, the higher the optical densities and the optical densities decreased as time increased from a minute to five minutes showing that platelets were aggregated.

Table 1: Group 1 (Control Group)

\begin{tabular}{|c|c|c|c|c|}
\hline \multicolumn{5}{|c|}{ Readings (Minutes) } \\
\hline $1 \mathrm{~min}$ & $2 \min$ & $3 \mathrm{~min}$ & $4 \mathrm{~min}$ & $5 \mathrm{~min}$ \\
\hline 0.643 & 0.522 & 0.479 & 0.470 & 0.466 \\
\hline 0.745 & 0.737 & 0.730 & 0.726 & 0.718 \\
\hline 0.699 & 0.676 & 0.658 & 0.655 & 0.634 \\
\hline 0.573 & 0.562 & 0.554 & 0.552 & 0.542 \\
\hline 0.471 & 0.462 & 0.457 & 0.455 & 0.442 \\
\hline 0.504 & 0.496 & 0.486 & 0.480 & 0.469 \\
\hline 0.605 & 0.575 & 0.559 & 0.555 & 0.545 \\
\hline
\end{tabular}

Table 2: Group 2 (200mg/Kg Body Weight of the Extract)

\begin{tabular}{lllll}
\hline Readings (Minutes) & \multicolumn{5}{c}{} \\
\hline $1 \mathrm{~min}$ & $2 \mathrm{~min}$ & $3 \mathrm{~min}$ & $4 \mathrm{~min}$ & $5 \mathrm{~min}$ \\
\hline 0.367 & 0.364 & 0.361 & 0.361 & 0.359 \\
0.583 & 0.574 & 0.573 & 0.571 & 0.569 \\
0.563 & 0.540 & 0.512 & 0.504 & 0.499 \\
0.860 & 0.877 & 0.876 & 0.874 & 0.872 \\
0.887 & 0.775 & 0.768 & 0.760 & 0.756 \\
0.312 & 0.270 & 0.260 & 0.256 & 0.243 \\
0.595 & 0.566 & 0.558 & 0.555 & 0.550 \\
\hline
\end{tabular}

Table 3: Group 3 (100mg/Kg Body Weight of the Extract)

\begin{tabular}{lllll}
\hline Readings (Minutes) & & & & \\
\hline $1 \min$ & $2 \min$ & $3 \min$ & $4 \min$ & $5 \min$ \\
\hline 0.512 & 0.501 & 0.489 & 0.486 & 0.481 \\
0.326 & 0.317 & 0.311 & 0.311 & 0.308 \\
0.745 & 0.741 & 0.739 & 0.738 & 0.738 \\
0.523 & 0.520 & 0.517 & 0.511 & 0.499 \\
0.387 & 0.373 & 0.373 & 0.374 \\
0.397 & 0.377 & 0.377 & 0.375 & 0.372 \\
0.481 & 0.377 & 0.467 & 0.465 & 0.462 \\
\hline
\end{tabular}


Table 4: Group 4 (50mg/Kg Body Weight Of Extract)

\begin{tabular}{|c|c|c|c|c|}
\hline \multicolumn{5}{|c|}{ Readings (Minutes) } \\
\hline $1 \mathrm{~min}$ & $2 \min$ & $3 \mathrm{~min}$ & $4 \mathrm{~min}$ & $5 \mathrm{~min}$ \\
\hline 0.278 & 0.276 & 0.275 & 0.274 & 0.270 \\
\hline 0.416 & 0.412 & 0.407 & 0.404 & 0.400 \\
\hline 0.486 & 0.480 & 0.476 & 0.471 & 0.470 \\
\hline 0.366 & 0.365 & 0.364 & 0.364 & 0.360 \\
\hline 0.723 & 0.719 & 0.714 & 0.710 & 0.705 \\
\hline 0.513 & 0.512 & 0.508 & 0.504 & 0.500 \\
\hline 0.463 & 0.460 & 0.457 & 0.454 & 0.450 \\
\hline
\end{tabular}

Table 5: In Vitro Test

\begin{tabular}{lllll}
\hline \multicolumn{2}{l}{ Readings (Minutes) } & & & \\
\hline $1 \mathrm{~min}$ & $2 \mathrm{~min}$ & $3 \mathrm{~min}$ & $4 \mathrm{~min}$ & $5 \mathrm{~min}$ \\
\hline 0.671 & 0.669 & 0.664 & 0.660 & 0.656 \\
0.473 & 0.468 & 0.467 & 0.462 & 0.460 \\
0.601 & 0.601 & 0.597 & 0.591 & 0.590 \\
0.677 & 0.670 & 0.667 & 0.661 & 0.661 \\
0.729 & 0.723 & 0.722 & 0.718 & 0.716 \\
0.881 & 0.877 & 0.874 & 0.870 & 0.869 \\
0.672 & 0.668 & 0.665 & 0.660 & 0.659 \\
\hline
\end{tabular}

Table 6: Absorbance of the Control and Test Groups Sample at a Wavelength of 600nm

\begin{tabular}{|c|c|c|c|c|c|}
\hline Time (Minutes) & 1 & 2 & 3 & 4 & 5 \\
\hline Group 1 (control) & $0.605 \pm 0.003$ & $0.575 \pm 0.002$ & $0.559 \pm 0.001$ & $0.555 \pm 0.001$ & $0.545 \pm 0.001$ \\
\hline $\begin{array}{l}\text { Group } 2(200 \mathrm{mg} / \mathrm{kg} \text { body } \\
\text { weight of extract) }\end{array}$ & $0.595 \pm 0.015$ & $0.566 \pm 0.001$ & $0.558 \pm 0.003$ & $0.555 \pm 0.004$ & $0.550 \pm 0.007$ \\
\hline $\begin{array}{l}\text { Group } 3(100 \mathrm{mg} / \mathrm{kg} \text { body } \\
\text { weight of extract) }\end{array}$ & $0.481 \pm 0.006$ & $0.472 \pm 0.001$ & $0.467 \pm 0.001$ & $0.465 \pm 0.002$ & $0.462 \pm 0.003$ \\
\hline $\begin{array}{l}\text { Group } 4 \quad(50 \mathrm{mg} / \mathrm{kg} \text { body } \\
\text { weight of extract) }\end{array}$ & $0.463 \pm 0.003$ & $0.460 \pm 0.002$ & $0.457 \pm 0.005$ & $0.454 \pm 0.001$ & $0.459 \pm 0.003$ \\
\hline
\end{tabular}

Data represented as mean \pm standard deviation (SD)

\section{Conclusion}

In conclusion, the optical densities of the platelet-rich plasma of rats treated with different doses of the extract, decreased with time which implies that C. olitorus has platelet-aggregatory effect. C. olitorus is therefore, recommendable to people with various degrees of wounds to help them speed up the healing of their wounds.

\section{Acknowledgements}

Authors wish to acknowledge Prof. C.O. Okeke, of the Department of Botany, Nnamdi Azikiwe University, Awka for taking out time to authenticate the plant sample.

\section{References}

[1] L. Makhubu, Biopropecting in an African context. Science, 282, 1998, $41-42$.

[2] A. Sofowora, the State of Medicinal Plants Research in Nigeria; Proceedings of a Workshop, Ife, Osun state, Nigeria, 1986.

[3] L. G. Holm, J. U. Pancho, J. P. Herberger, and D. L. Plucknett, A geographical atlas of world weeds. (New York, John Wiley and Sons, 1979).

[4] J. U. A. Duke, and K. K. Wain. Medical plants world. National Journal of American Society, 3, 1981, 58-60.

[5] C. Qomen, and S. E. Grudden, "Nutrients in Jute (Corchorus olitorus)". American Society, 4(3), 1978, 345-349

[6] N. C. Pan, A. Day, K. K.and Mahalmabis, K.K. "Properties of Jute". India Textile Journal, 110(5), 2000,16

[7] M. J. Dijkstra-tiekstra, C. E. Vander Schoot, R. N. Pietersz, and H. W. Resink. White blood cell fragment in platelet concentrate is prepared by the platelet rich plasma or buffy coat methods. Vox Sang, 88, 2005, 275-277. 